\title{
THE RADIOLOGY OF ACUTE PULMONARY EDEMA
}

BY

\author{
FREDERIC JACKSON
}

Clinical Assistant, 1947-48, and Paterson Medical Officer, Cardiac Department, The London Hospital, 1949-50

Received January 12, 1951 ,

The purpose of this paper is to describe some of the X-ray appearances of acute pulmonary œdema occurring in heart failure, and to distinguish them from other shadows in the lung commonly associated with heart disease. It is based on films of patients taken during attacks of breathlessness due to acute pulmonary œdema. The films were usually taken in the ward with a portable $\mathrm{X}$-ray apparatus, a procedure causing little discomfort to the patient, though with the inherent disadvantages of a short tube-distance and a longer exposure time. Teleradiograms at six feet were taken at once in a few cases when the patient was admitted to hospital during an attack. Not every patient with paroxysmal dyspnœa shows the radiological changes of acute pulmonary œdema, especially if the attack is mild; but such changes are frequently evanescent so that if examination is delayed even a few hours they may have vanished.

Twènty cases are included in this series: 10 had hypertensive heart failure, comprising 2 with malignant hypertension, 4 with nephritis, and 4 without renal involvement; another without hypertension, had great enlargement of the left ventricle and left bundle branch block; three patients had aortic incompetence, 1 due to bacterial endocarditis and 2 due to syphilis, but in one of these heart failure was due to cardiac infarction. There were 6 cases of mitral stenosis, all women, and all in normal rhythm except one with auricular fibrillation where acute pulmonary œdema was caused by a blood transfusion.

\section{General Features}

Acute pulmonary œdema appears on the film as dense cloudy opacities covering both hilar regions, often obscuring all details of the lung roots and of the adjacent lung structures. The shadows spread outwards from the hila over the central portions of the lung fields and down into the lung bases; it is noteworthy, however, that the apices of the lungs above are usually unaffected, and so quite often are the costophrenic angles below (Fig. 1A, 11A, and 12B). Occasionally the opacities affect mainly the hilar region and do not extend far into the lung field (Fig. 8A and 17A), or the main density is perihilar and softer clouds lie farther out towards the periphery (Fig. 9A and $16 \mathrm{~A})$.

The cloudiness usually ends before it reaches the chest wall, so that the periphery of the lungs with the apices and the costophrenic angles form a continuous light outer zone (Fig. 1A and 3). In very severe cases or with repeated attacks, the cloudy areas extend to the chest wall and only the apices escape (Fig. 4A and 12A). Both lungs are always simultaneously affected, though sometimes one more than the other. In the anterior view there is no tendency towards a lobar or segmental distribution of the opacities which radiate from the hila without regard to the anatomical divisions of the lungs. Here acute pulmonary œdema differs from pulmonary infarction, which is frequently confined to one side and limited to a portion of a lobe. 
The shadowing often takes one of two forms. In one there is a dense cloudiness or blotchiness composed of large uneven opacities, frequently confluent, which obscure the pattern of the lungs (Fig. 1A, 2, and 6); in the hilar regions the density blots out the pulmonary vessels, and below them it may partly hide the outline of the heart (Fig. 4A, 12A, and 16A); this contrasts with severe pulmonary congestion without œdema, where the vascular markings of the lung fields are increased and the lung roots appear as a condensed mass capping each hilum (Fig. 4B and 5). Where the shadowing is dense and uneven there is an appearance of blotchiness rather than cloudiness, though here also the markings of the lungs are concealed (Fig. 11A and 19A). In regions where the large opacities are diffuse and faint, pinhead stippling may appear (Fig. 10A); the stippling fades towards the outer part of the lung, and vanishes when the œdema clears (Fig. 10B).

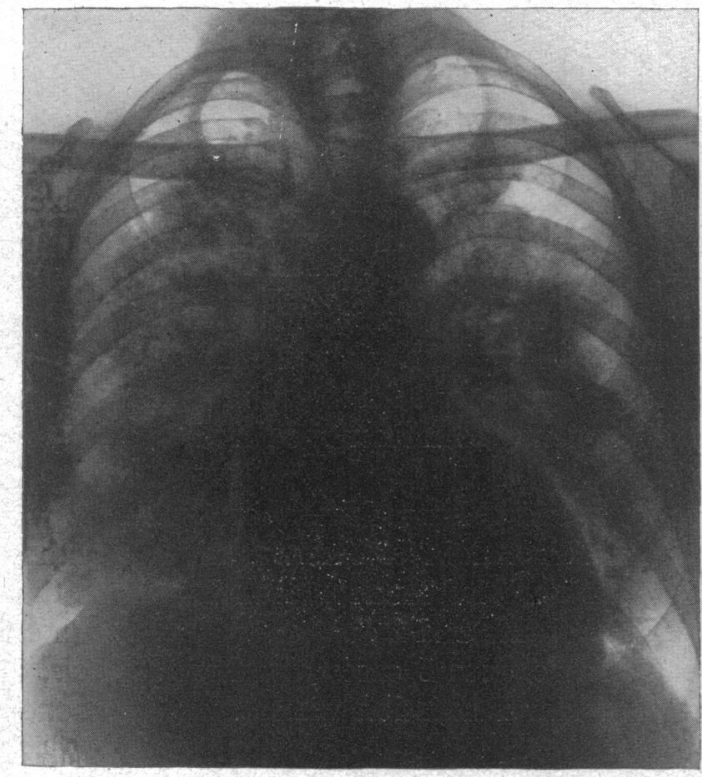

A

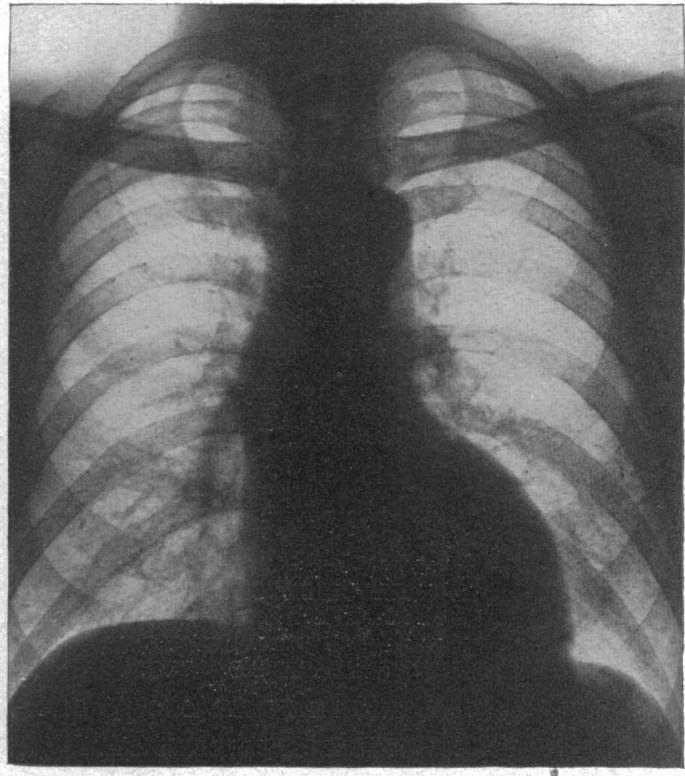

B

FIG. 1.-Malignant hypertension. (A) Acute pulmonary œdema. Teleradiogram showing extensive cloudy opacities in the central and basal parts of the lungs. The apices and costophrenic angles are spared and there is a continuous light outer zone. No crepitations were audible clinically. Blood urea $67 \mathrm{mg}$. per $100 \mathrm{ml}$. (B) One month later following treatment with digitalis and mersalyl. Lung fields clear. No hilar congestion. The diaphragm is only slightly lower and the heart has hardly changed in size. Cardiothoracic ratio 52 per cent in (A); 50 per cent in (B).

In the second and less common variety of shadowing there is a great overall loss of translucency of the lung fields, and the opacities take the form of blurred branched finger-like processes radiating from the hila (Fig. 13A); or, it may be, of blurred speckling in which the branching is less conspicuous. Close-up views of the lung show the darkened field, and in one case small cloudy opacities mingle with the ill-defined outlines of enlarged divisions of the pulmonary vessels (Fig. 15); in another, blurred speckling is seen without obvious branching (Fig. 14). In this second variety of pulmonary œdema the hilar vessels and the lung structure are not completely hidden, though almost the whole of the lung field may be affected. The significance of the varied appearance of the lung shadows is discussed later.

Hilar congestion, sometimes of severe degree (Fig. 13A), is evident when the lung roots are not entirely obscured. With recovery from the attack hilar congestion usually persists after the other opacities have disappeared (Fig. 4B and 13B), but the hilar shadows may also return to normal with treatment (Fig. 1B).

Hydrothorax is unusual in isolated attacks of acute pulmonary œdema, and in 15 of my 20 cases 
the lateral costophrenic angles remained free from fluid. With frequently recurring severe left ventricular failure, or when right ventricular failure is added, hydrothorax is more often demonstrable; pulmonary infarction associated with acute pulmonary odema is also likely to cause effusion. An example of a large hydrothorax with acute pulmonary œdema is seen in Fig. 4, and hydrothorax on the left side due to infarction of the left lower lobe, confirmed at necropsy, with acute pulmonary œdema is shown in Fig. 3. Though large effusions are seldom seen in uncomplicated acute pulmonary odema, frequent evidence of a pleural reaction is seen in the thickening of the interlobar fissure on the right side, thought to be due to a layer of fluid on the pleural surfaces lining it (Fig. 4A, $8 \mathrm{~B}$, and $9 \mathrm{~A})$.

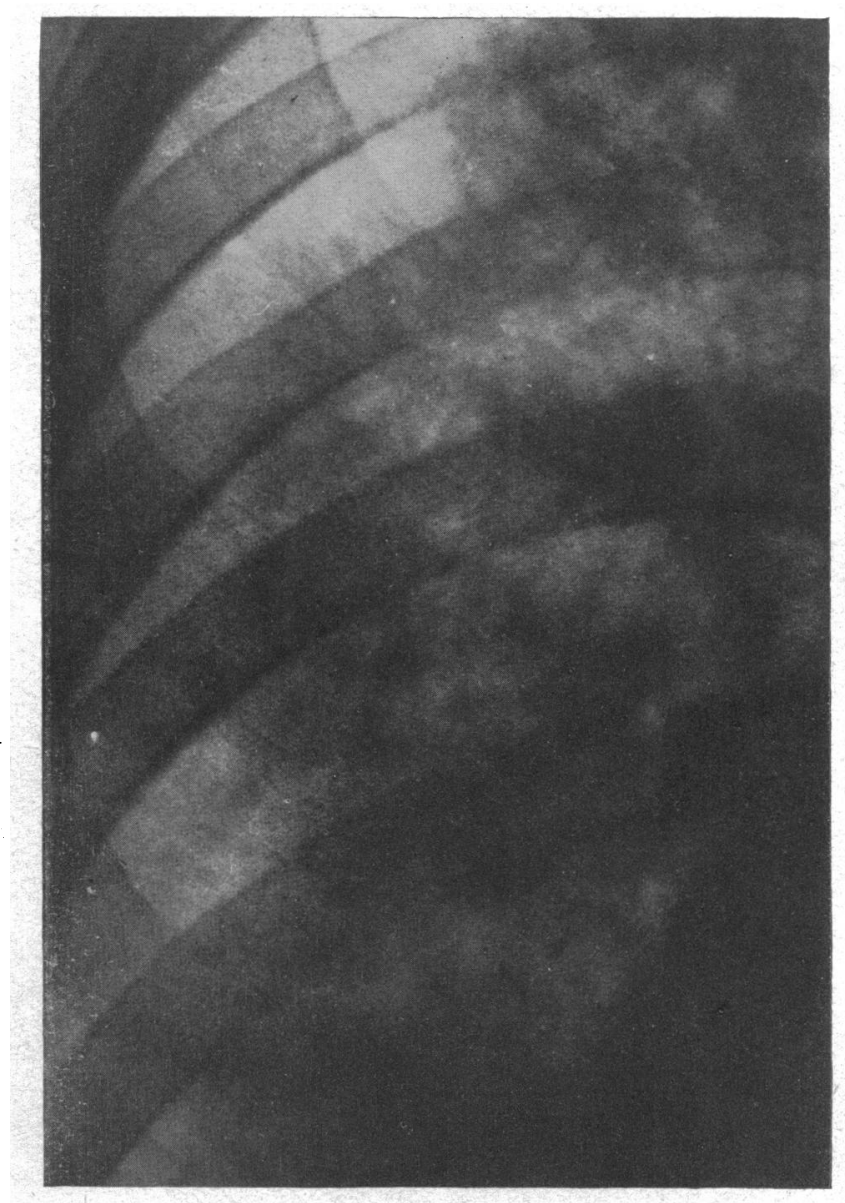

Fig. 2.-Portion of right lung field in Fig. 1(A), natural size. Shows diffuse uneven cloudiness which conceals the hilar structures and lung pattern.

The height of the diaphragm alters little during an attack (Fig. 1, 13, and 17); usually there is only slight elevation, or none at all, in contrast with the raised dome of chronic congestive failure and the persistent elevation resulting from pulmonary infarction. Dilatation of the superior vena cava is seldom seen, though sometimes its outline is too obscured to be certain of its limits.

The heart is almost always increased in size and altered in shape, both these depending on the underlying heart disease. The enlargement is frequently much less than might be expected, and is sometimes very slight in mitral stenosis (Fig. 17). Moderate enlargement is usual with hypertension (Fig. 1, 4, and 8), and great enlargement of the left ventricle was seen with left bundle branch 


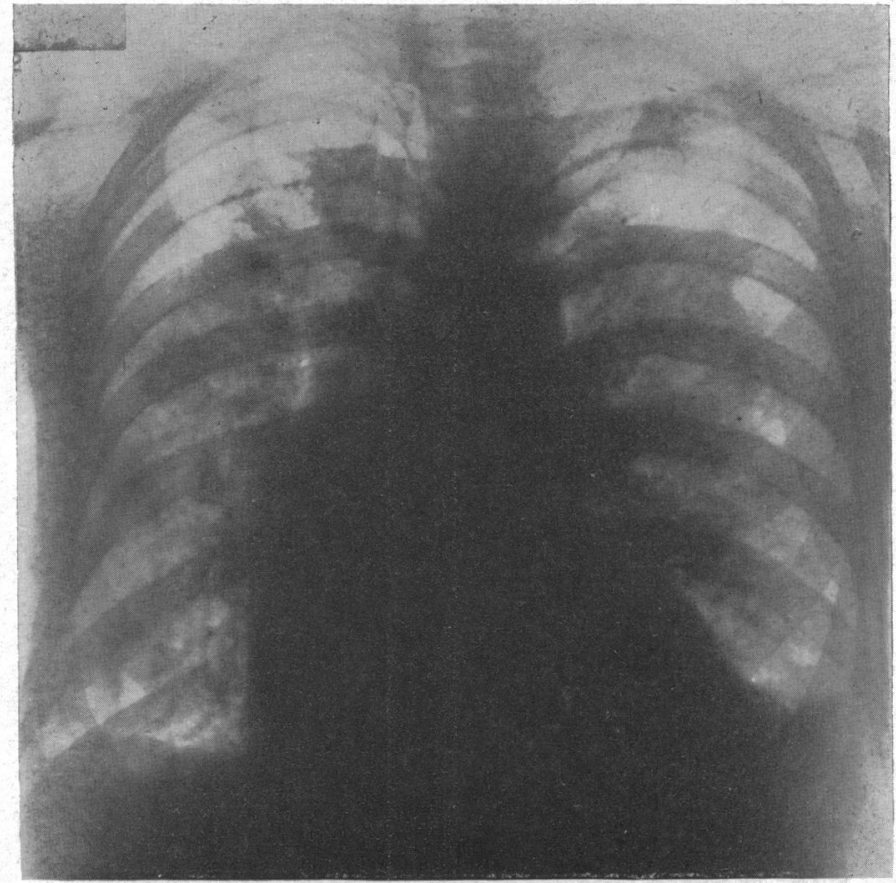

Fig. 3.-Chronic nephritis and hypertension. Acute pulmonary œedema. Dense uneven shadowing affecting the central parts of the lungs. Apices spared and light zone at the periphery. Left hydrothorax from infarction of left lower lobe.' Post-mortem control.

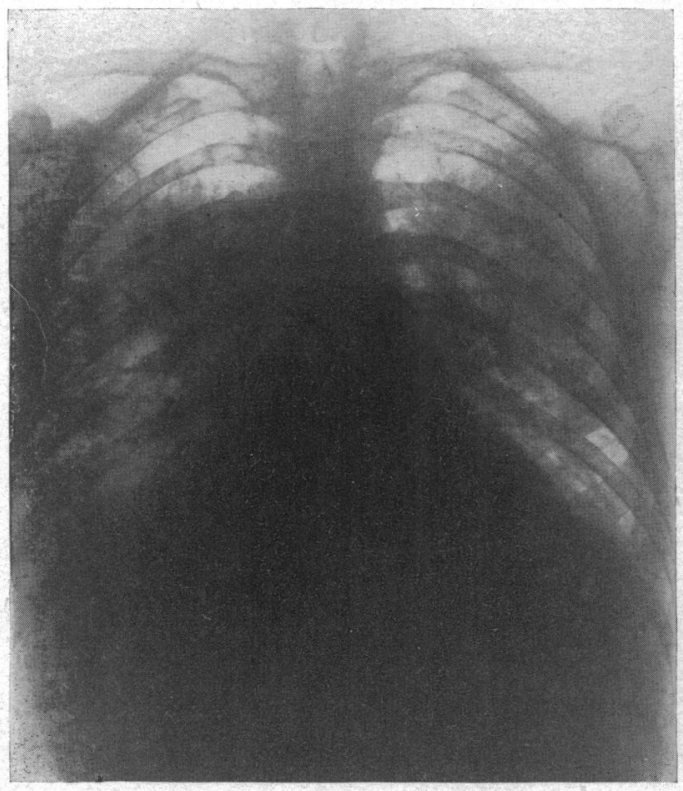

A

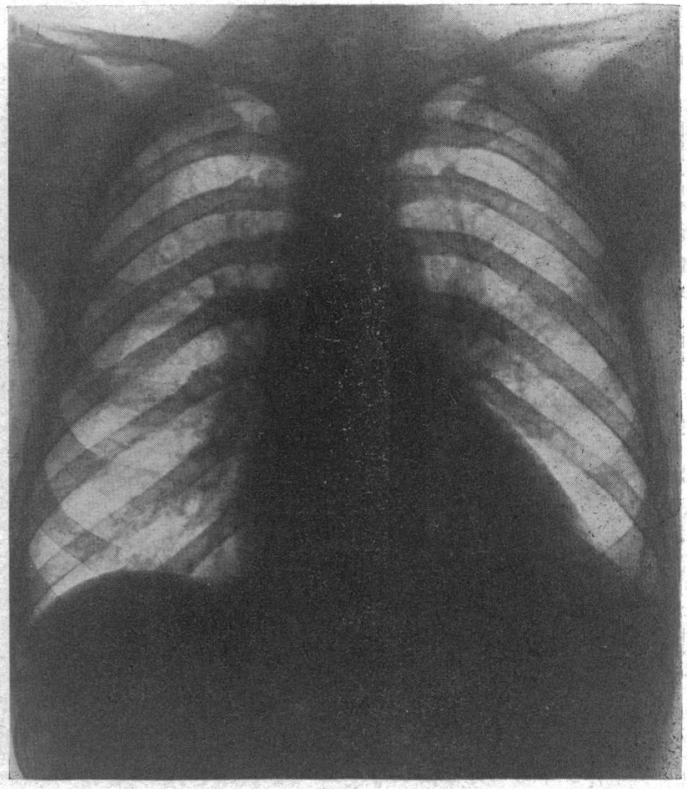

B

Fig. 4.-Hypertension. '(A) Acute pulmonary odema. Shadowing extends as far as the chest wall on both sides Apices clear, and lower part of left lung field less affected. Hilar vessels hidden and cardiac outline partly obscured. Right interlobar fissure visible. Normal renal function. (B) Nine days later. Lung opacities gone. Severe pulmonary congestion remains. Left hydrothorax. Heart enlarged. 
block (Fig. 9) and with aortic incompetence (Fig. 11). The shape and size of the heart change little or not at all, during an attack and with recovery (Fig. 1, 9,11, 13, 17, and 19).

\section{The Regression OF THE X-RAY Signs}

The X-ray changes of acute pulmonary œdema frequently disappear with remarkable rapidity, and for this reason they are often missed. Once the lung fields cleared within 14 hours of the onset of the attack (Fig. 9), and in three others within 24-48 hours (Fig. 16, 17, and 19). In two more, very extensive lung shadows disappeared within a few days-in one after 3 days, though severe

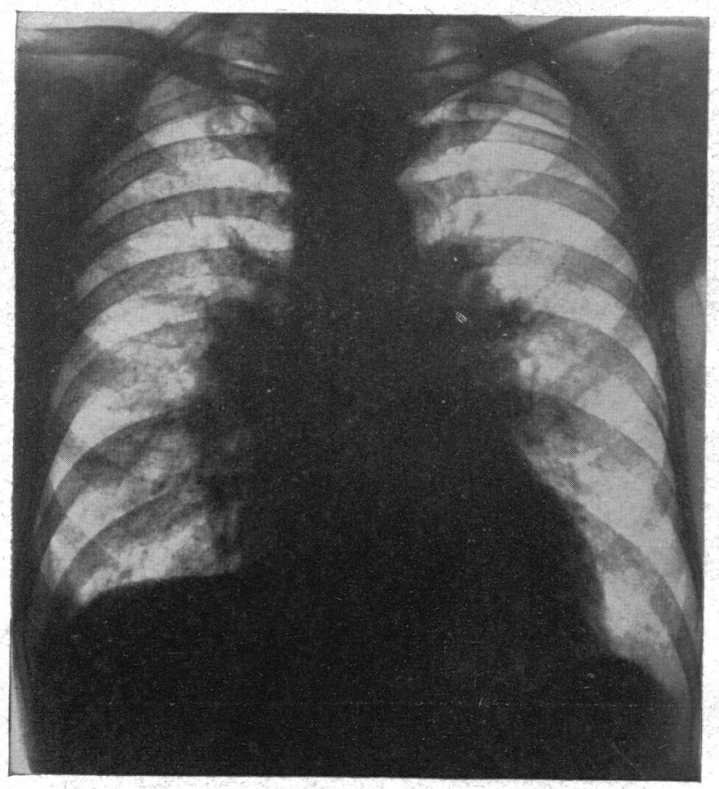

Fig. 5.-Severe pulmonary congestion without pulmonary cedema. Bacterial endocarditis of the mitral valve. Post-mortem' control.

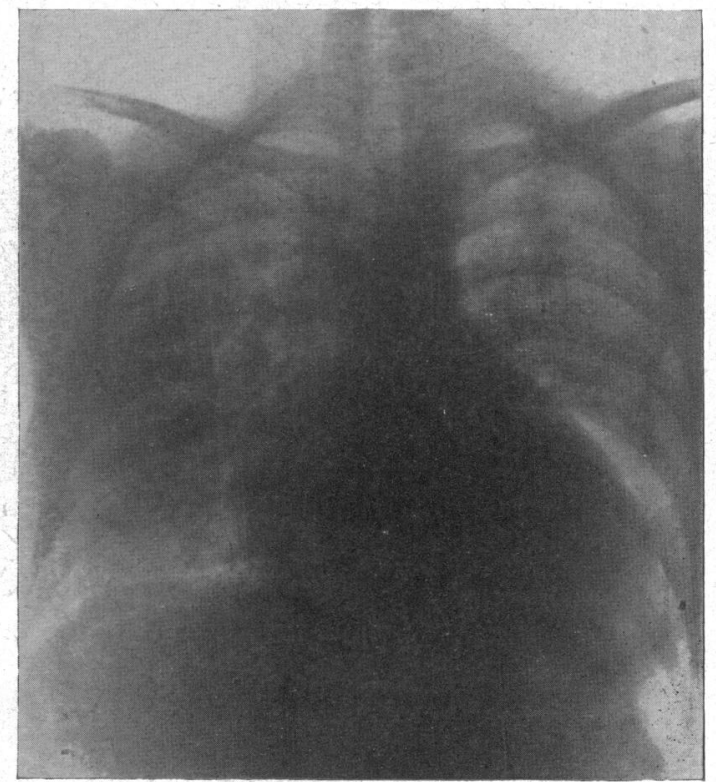

FIG. 6.-Pyelonephritis with uræmia. Hypertension. Acute pulmonary œdema. Portable X-ray the day before death. Widespread blotchy opacities extending to the chest wall. Apices and costophrenic angles spared. No hydrothorax post mortem.

pulmonary congestion remained (Fig. 18), and in the other after 4 days, when all trace of pulmonary œdema had gone(Fig. 11). The early clearing of the lung fields helps to distinguish acute pulmonary from the pneumonias, where resolution commonly takes longer, and also from the shadow of pulmonary infarction, a likely complication of heart failure, which may persist for several weeks. The disappearance of the pinhead stippling in Fig. 10 differentiates it from the somewhat similar shadowing of hæmosiderosis; lung opacities due to tuberculosis, carcinoma, silicosis, and sarcoid are also distinguishable from acute pulmonary œdema by their much slower development on the $\mathrm{X}$-ray.

\section{Discussion}

Acute pulmonary œdema falls clinically into two groups depending on whether the attack is a single isolated episode followed by recovery, or whether a number of attacks are recurrent events in the course of progressive left ventricular failure. The term sub-acute pulmonary œdema has been applied to the recurrent variety (Antonelli, 1935; Zdansky, 1939; and Lenègre and Minkowski, 1946). In it the radiological picture of pulmonary œdema is often surprisingly extensive, and may persist between attacks when clinical signs and symptoms have temporarily abated (Fig. 12B). It 


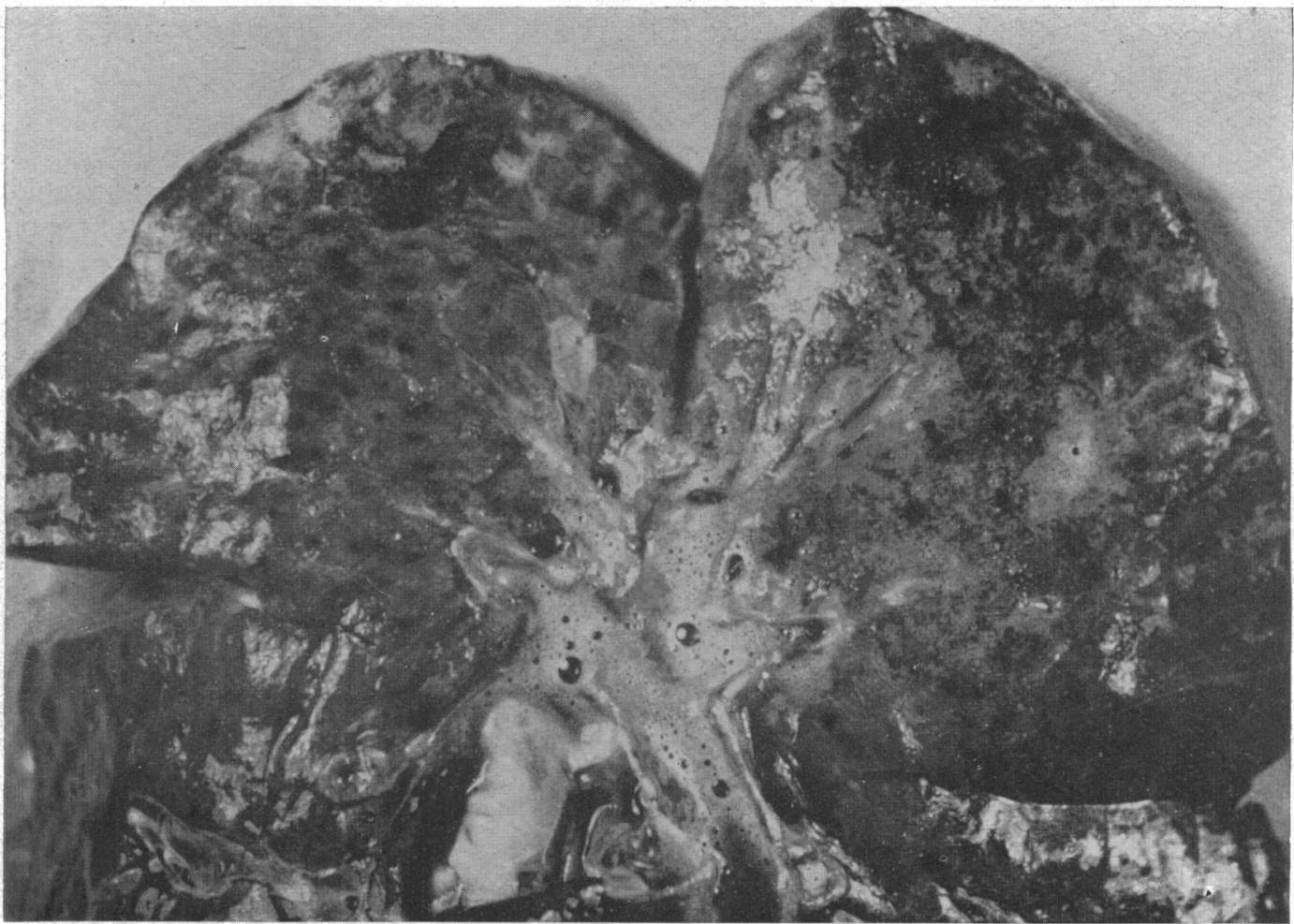

Fig. 7.-Photograph of the lung of patient in Fig. 6 showing pale frothy fluid exuding from the cut surface and filling the bronchi.
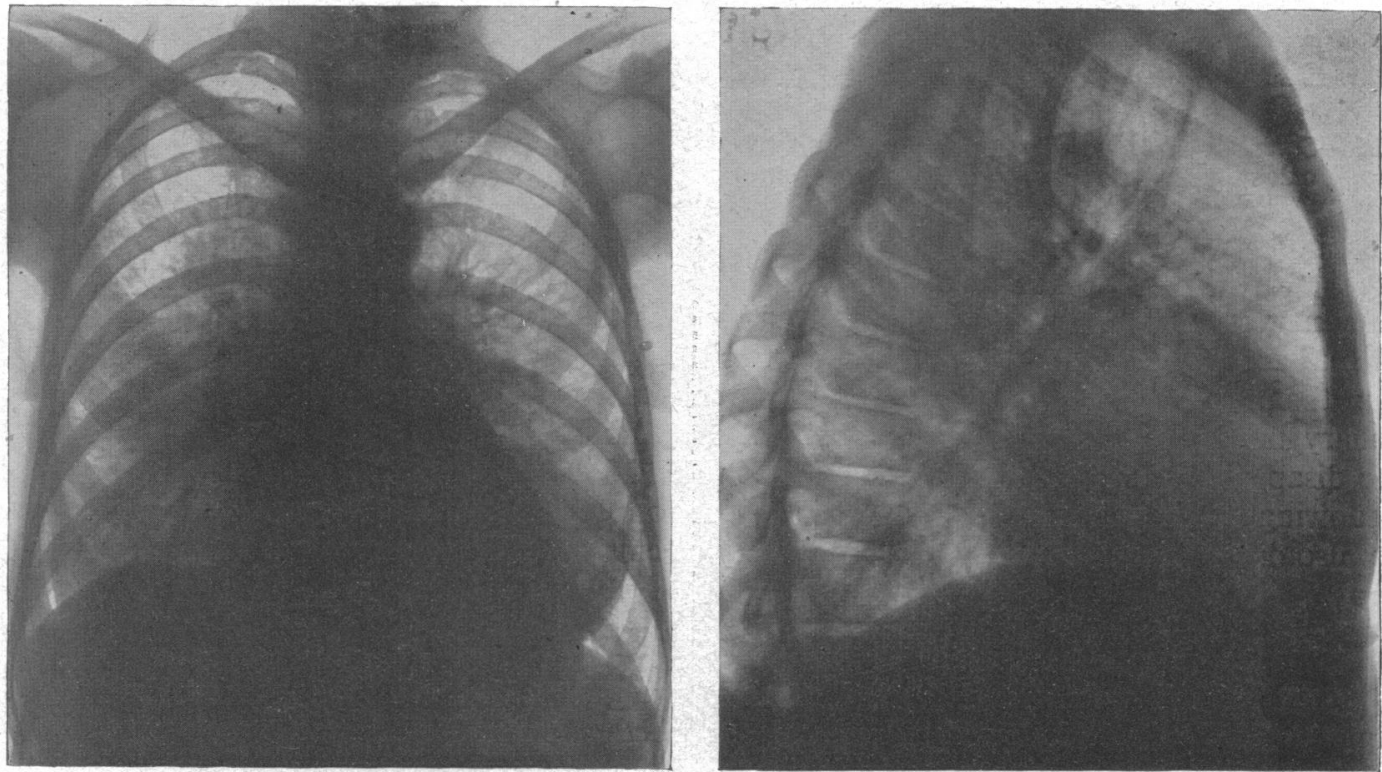

A

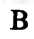

FIG. 8.-Chronic nephritis and hypertension. Recurrent acute pulmonary odema. (A) Anterior view. Opacities mainly perihilar with radiating strands. Lateral costophrenic angles clear. Heart moderately enlarged. (B) Right lateral view. Small right posterior hydrothorax which was hidden in the anterior view. Fluid in the interlobar fissures. Net-like appearance of the lung markings. 


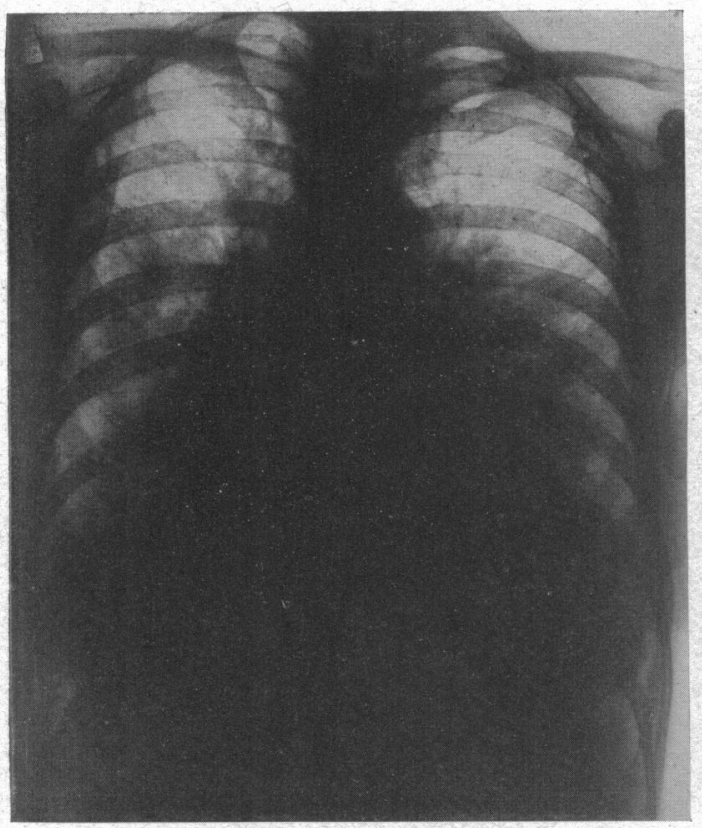

A

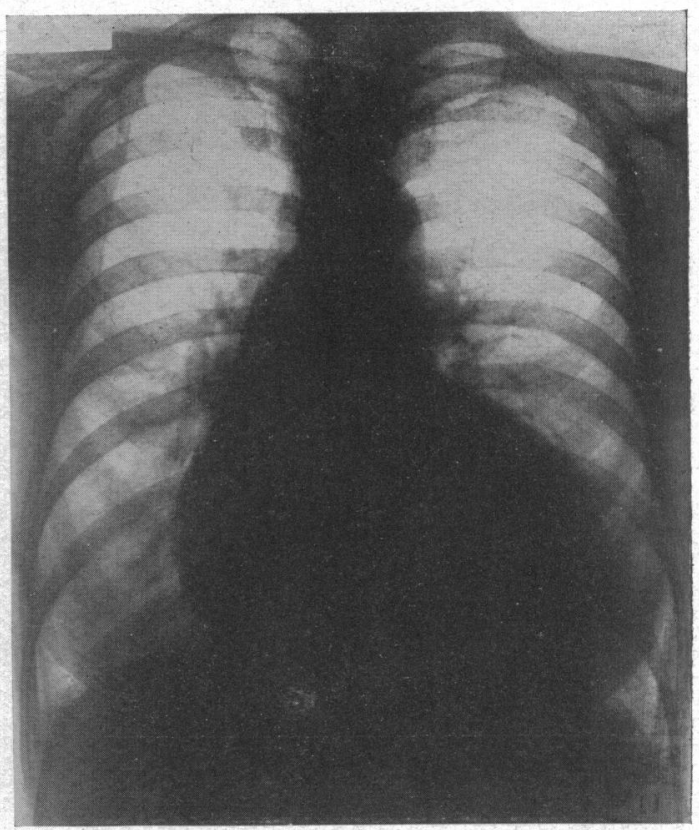

B

Fig. 9.-Left bundle branch block. Large left ventricle. (A) Teleradiogram during an attack of acute pulmonary odema. The main density is perihilar with softer clouds farther out, better seen on the right side. Apices and costophrenic angles clear. Right interlobar fissure, visible. (B) Teleradiogram 14 hours later after morphia injection. Lung fields entirely clear. Height of diaphragm and size of heart unchanged. Cardiothoracic ratio, 70 per cent.

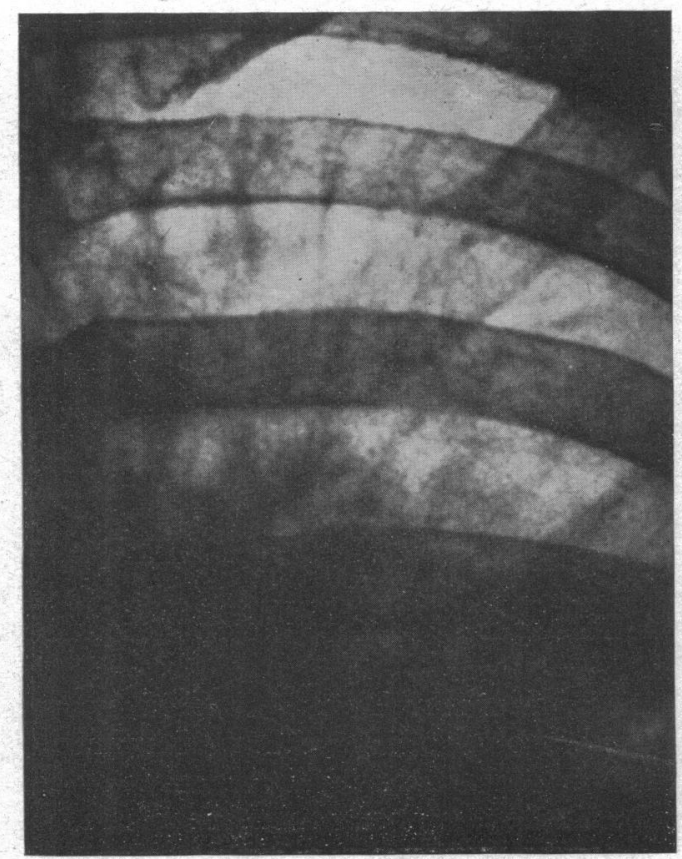

A

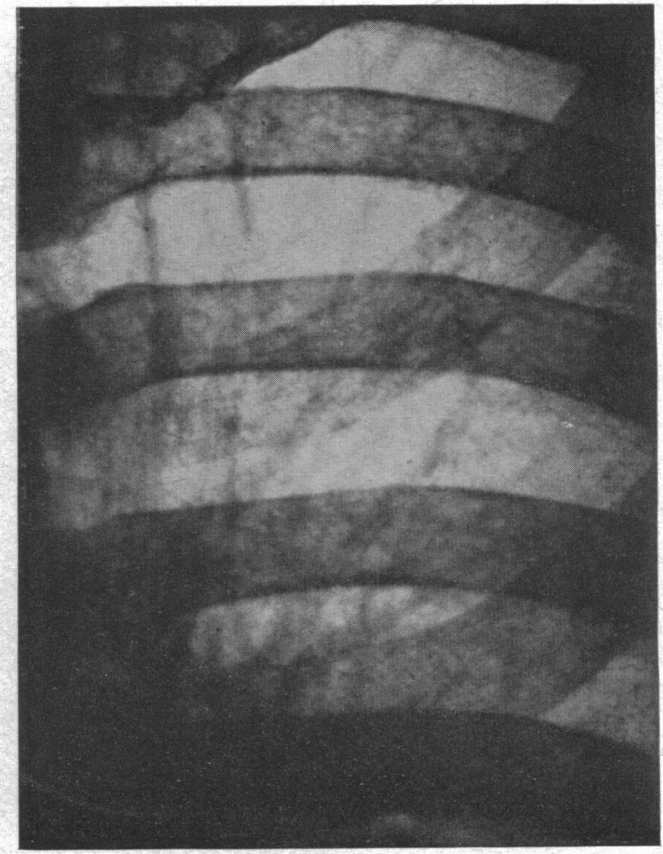

B

Fig. 10.-Close-up views of the left lung field above the hilum in Fig. 9. Natural size. (A) Pinhead stippling in the outer part of the shadowing. (B) After recovery the pinhead stippling has gone. 


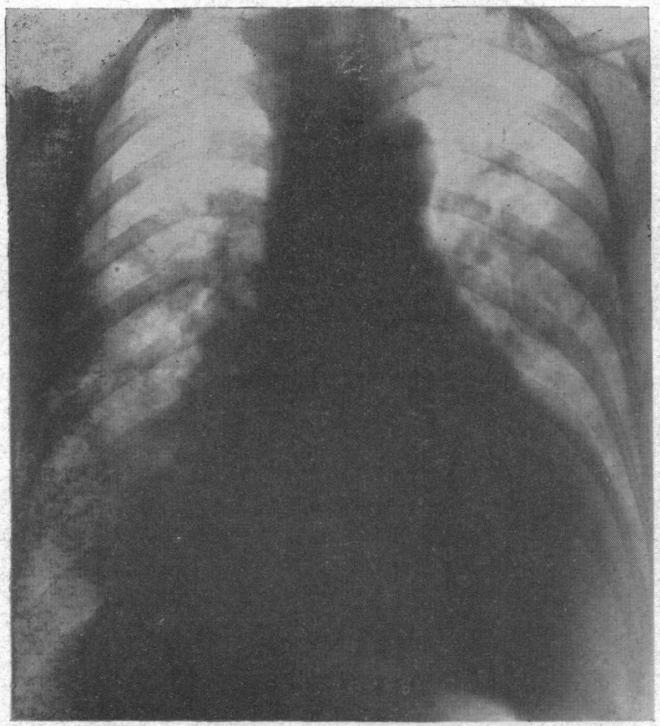

A

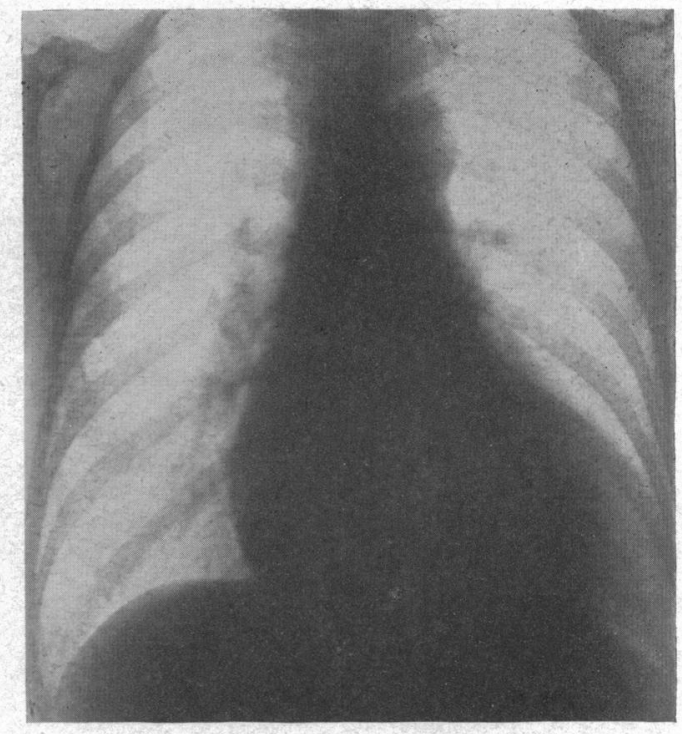

B

FIG. 11.-Syphilitic aortic incompetence. (A) Acute pulmonary œdema. Uneven blotchy opacities in central and basal lung fields. Apices clear. Diaphragm not raised. (B) Four days later. Treatment with morphia and digitalis. Lung fields clear. Very large left ventricle unchanged in size. Cardiothoracic ratio, 68 per cent.

is to this group that the so-called " uræmic lung" belongs, and the occasional case of severe pulmonary œdema appearing as an unexpected radiological finding. Since, however, the two groups do not permit a radiological distinction, the division is not maintained in this paper. Besides, examples in the first group may progress into the second, and some of those with persistent signs of pulmonary œdema may recover with adequate treatment.

\section{The LUNG Shadows}

The cloudy opacities of acute pulmonary œdema have been called "butterfly " or " bats-wing shadowing," thus emphasizing both the bilateral distribution and the characteristic extension into the central and basal parts while sparing the apices and the periphery. Both lungs were simultaneously affected in all my 20 cases, though sometimes unequally. Other authors believe the shadowing may affect one lung alone or even one lobe, and Nessa and Rigler (1941) showed an example of œdema of the whole of the right lung without involvement of the left (Felson and Heublein, 1948; and Hodson, 1950); such cases of unilateral acute pulmonary œedema in heart failure are very rare. Where one lung is more affected than the other it is usually the right, and this was so in 6 of my 7 cases showing unequal involvement; in 2 added infection was thought to be responsible (Fig. 18), and may even have caused the attacks of acute pulmonary œdema. Zdansky (1933) and Weiss (1941 and 1942) both remarked on the greater susceptibility of the right lung, and Werkenthin (1939) discussing possible causes of unusual distribution thought the position of the patient influenced the localization of the œdema in the lungs.

The shadowing may take the form of dense clouds, or it may have a branched or speckled appearance; sometimes it is intermediate between these two varieties or differs with the position in the lung field. Subdivision of the shadows into nodular and net-like forms was made by Lenègre and Minkowski (1946), who mentioned the resemblance to the pneumonias, neoplasm, miliary tubercle, sarcoidosis, and silicosis, and an even more detailed classification was attempted by Donzelot and Heim de Balzac (1947). Fine stippling in the outer zone of shadowing was once seen in a teleradiogram taken during an attack (Fig. 10), and it re-appeared during subsequent bouts of 


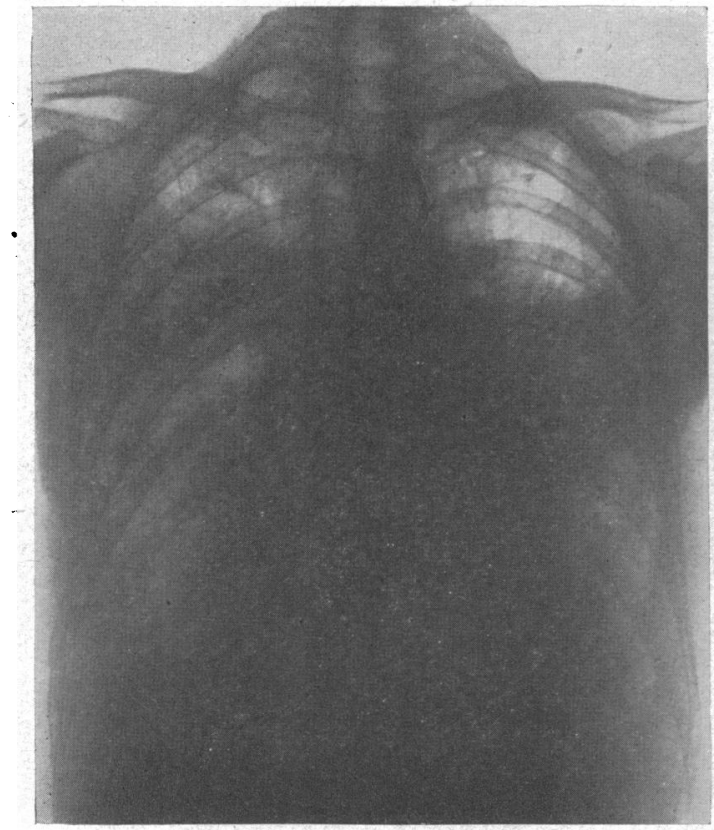

A

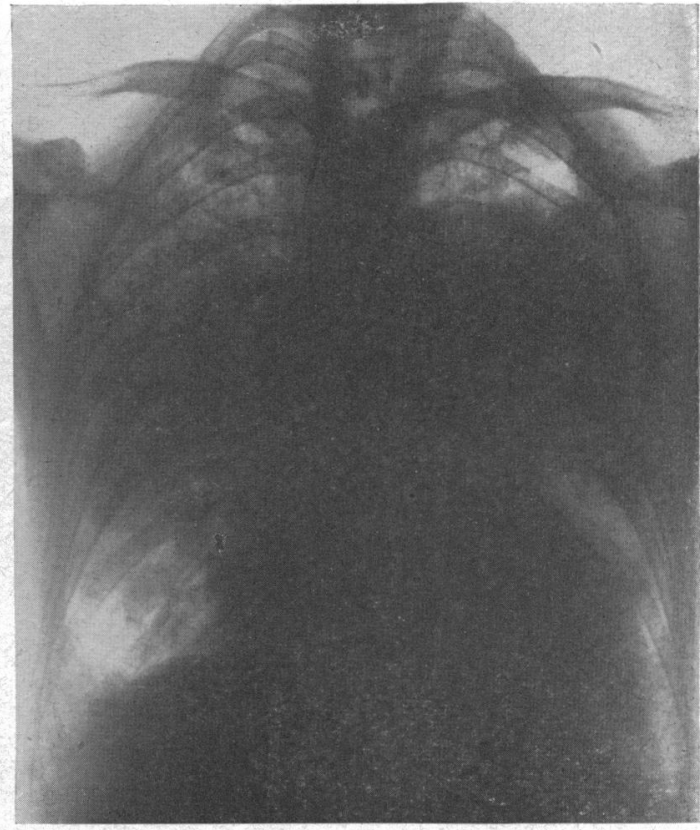

B

FIG. 12.-Bacterial endocarditis. Aortic incompetence. Recurrent attacks of acute pulmonary œdema. (A) Five days after onset of attacks; seven days before death. Very dense and extensive shadowing. Apices spared. (B) Two days before death during a temporary remission of symptoms between attacks. Extensive opacities persist on both sides though the apices and lower lung fields are relatively clear. Lungs not infected post mortem. Adherent pleura. No hydrothorax.

acute pulmonary œdema. Minute opacities were also seen by Roubier and Plauchu (1933) using a hand-lens, to which they applied the term " fin piqueté." The infrequency of this type of shadowing may be partly due to the lack of definition in portable films.

The reason for the varied picture of acute pulmonary œdema is not clear; in part it may be determined by the stage in the development and absorption of the œdema at which the film is taken (Hodson, 1950). Any explanation of the shadowing in the lungs is largely speculative, though some help is obtained from pathological examination if the time interval before death is short. An increase in the fluid content of the lung tissues, distributed evenly, will cause a generalized loss of translucency on the film, or a layer of fluid in an oblique fissure may have a similar effect when viewed from the front (Fig. 8). There seems little doubt too, that localized collections of fluid in the air spaces of the lung are responsible for the dense cloudy opacities, since voluminous expectoration is not infrequent. Fig. 6 is a film taken the day before death, showing such widespread opacities, and at necropsy frothy fluid streamed from the cut surface of the lung (Fig. 7). Sometimes the œdema fluid is highly albuminous or even gelatinous (Doniach, 1947), which may explain how extensive opacities can be present in the X-ray when there is no sputum. Smaller collections of fluid confined to lobules of the lung would account for the speckled shadows (Fig. 14), and fluid-filled trefoils of alveoli for the pinhead stippling (Fig. 10). Lendrum et al. (1950) saw microscopically fibrinous coagulum in small groups of alveoli some three weeks after recovery from a short attack of cardiac asthma, where death was due to an unrelated cause. Edema of the interstitial tissues of the lung, of the vessel walls, and lung septa, combined with distension of the vessels themselves, probably gives rise to the branching effect (Fig. 13A and 15), and involvement of the smaller vessels to the finer strands or network that is sometimes seen (Fig. 8). Vessels seen end-on would contribute to the speckled effect accompanying the net-like appearance. 
Fig. 13.-Mitral stenosis. Normal rhythm. Acute pulmonary œdema. (A) Teleradiogram showing generalized loss of translucency of the lungs and blurred branched finger-like processes radiating from the hila. (B) One week later. Rest and digitalis. Lung fields brighter. Pulmonary vessels more sharply outlined. Much hilar congestion. Height of diaphragm and size of heart unchanged. Cardiothoracic ratio, 54 per cent:

The rapid disappearance of the opacities is of great help in their differentiation from other diseases (p. 507), and mention was made earlier of the lungs clearing within 14 hours of the onset of an attack of acute pulmonary œdema; Lenègre and Minkowski (1946) speak of recovery in under 24 hours, Weiss (1941) in 24-48 hours, and Coe and Otell (1932) in under 48 hours. Often, however, a severe attack takes a few days to resolve, or even a week or more (Hodson, 1950), and in one case of severe failure the picture of acute pulmonary odema persisted for nearly two weeks up to the time of death (Fig. 12). Rendich et al. (1941), mentioned the seriousness of the prognosis when the lung opacities persisted in spite of treatment, but Hodson (1950) found prognosis on the basis of the lung shadows difficult and emphasized that the condition was by no means always mortal.

Extensive lung opacities due to pulmonary œdema are sometimes discovered unexpectedly on X-ray when not previously suggested by the clinical signs (Zdansky, 1933; Roubier, 1938). Fig. 1A is such an example; crepitations were absent in the lung bases, though the patient was very breathless. The central distribution of the œdema leaving a clear outer zone of well-ærated lung is thought to be the explanation (Nessa and Rigler, 1941; Rennaes, 1948); such œdema may develop gradually so that a precise onset cannot be stated.

\section{HYDROTHORAX}

Opinions differ regarding the frequency of hydrothorax in acute pulmonary œdema. Clarity of the lateral costophrenic angles is usual in films in the frontal plane (as in 15 of my 18 cases without additional pulmonary infarction), but small hidden collections of fluid may still be present in the deeper posterior extensions (see Fig. 8). Lenègre and Minkowski (1946) noted blurring of the angle in oblique views, and obtained a few ml. of fluid on pleural puncture, usually on the right side, in 11 of 13 cases after major attacks of acute pulmonary odema. Fig. 6, on the other hand, 
FIG. 14.-Close-up view of right hilar region in Fig. 13(A). Natural size. Shows great loss of translucency and a blurred branching effect and also small ill-defined rounded opacities.

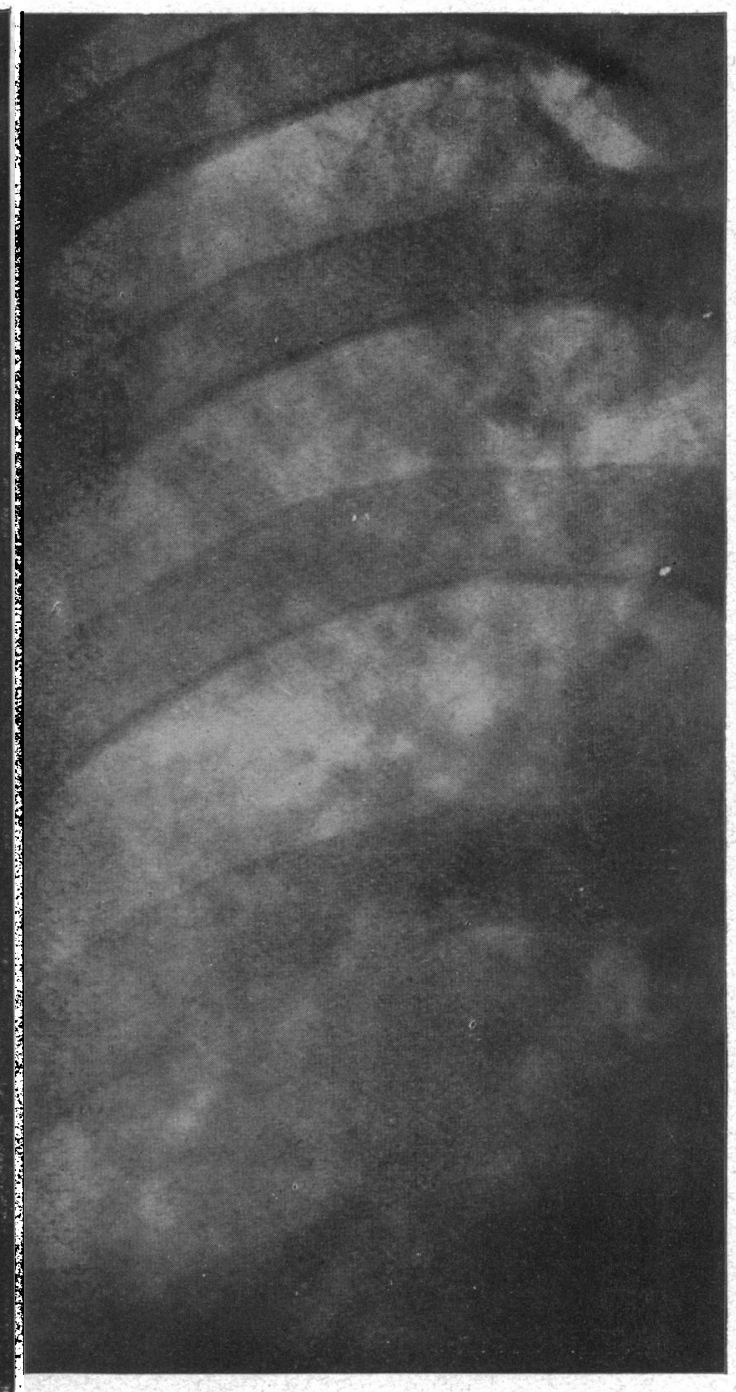

Fig. 15.-Close-up view of right lung field (natural size).in acute pulmonary cedema showing blurred speckling without obvious branching of the shadows. Syphilitic aortic incompetence and cardiac infarction. (Reduced X-ray not shown.) Contrast with Fig. 14.

shows severe acute pulmonary œdema the day before death, where no effusion into the pleural cavity was demonstrable post mortem, and similar findings have been reported before (Roubier and Plauchu, 1933; Doniach, 1947). Fishberg (1940) says hydrothorax never occurs in pure left ventricular failure, White et al. (1947) seldom saw it in the absence of added failure of the right ventricle, and Goodrich (1948) rarely found an associated hydrothorax. Alternatively, Bedford (1939), though his observations were not restricted to cases of acute pulmonary œdema, found hydrothorax in one-quarter of his cases of left ventricular failure. Zdansky $(1933,1939)$ found a small hydrothorax quite commonly with pulmonary œdema, especially in the nephritic group, and Dumas (1941) even used the term acute pleural œdema to describe acute pulmonary œdema with large hydrothorax; Roubier (1938) in a published film of an "azotæmic lung" from chronic 
FIG. 16.-Mitral stenosis. Normal rhythm. Acute pulmonary œdema. (A) Dense shadowing which obscures the hilar vessels and part of the cardiac outline. Fainter cloudiness farther out. Apices spared. (B) Next day: Most of the œdema has gone. Severe hilar congestion remains.

nephritis with uræmia showed a large left hydrothorax which had entirely cleared two months later. It therefore seems that although a considerable hydrothorax is unusual in acute pulmonary œdema, it may occur in about one-sixth of cases, and especially with repeated attacks or when right heart failure supervenes. Small collections of fluid in the posterior costophrenic angles, invisible in the frontal X-ray, are more common, and the frequent thickening of the interlobar fissure on the right side is evidence of increased pleural transudation.

\section{Uremia and Acute Pulmonary CEdema}

The association of uræmia with acute pulmonary œdema has excited interest in recent years. Severe uræmia was present in 2 of my 10 hypertensive cases, and slight uræmia in 2 more; in 3 the blood urea was normal and in 3 it was unknown, though 2 of these were without renal involvement and probably had normal levels. One patient with a high blood urea showed severe pulmonary œdema on the X-ray (Fig. 6) but the second did not; others with extensive radiological signs (Fig. 1A and 4A) had normal or but slightly elevated blood urea levels. The X-ray appearances in the two groups are similar, and examples of the so-called uræmic lung are indistinguishable from pulmonary œdema with a normal blood urea, left ventricular failure being the underlying cause in both. Zdansky (1933) thought pulmonary œdema due to renal disease differed radiologically from that of cardiac origin; so also did Roubier (1938) on the ground that symptoms of heart failure were minimal and remission of the $X$-ray changes accompanied diuresis and a fall in the blood urea. Later authors do not support this view. Rendich et al. (1941) showed that cardiac involvement with hypertension was always present, and on X-raying 50 uræmic patients without heart failure, they found none with pulmonary edema. Doniach $(1947,1949)$ with 11 reported cases of uræmia and pulmonary œdema and 5 more of his own (4 with necropsy control), found no radiological difference from uncomplicated left ventricular failure, and Hodson (1950) came to the same conclusion. 


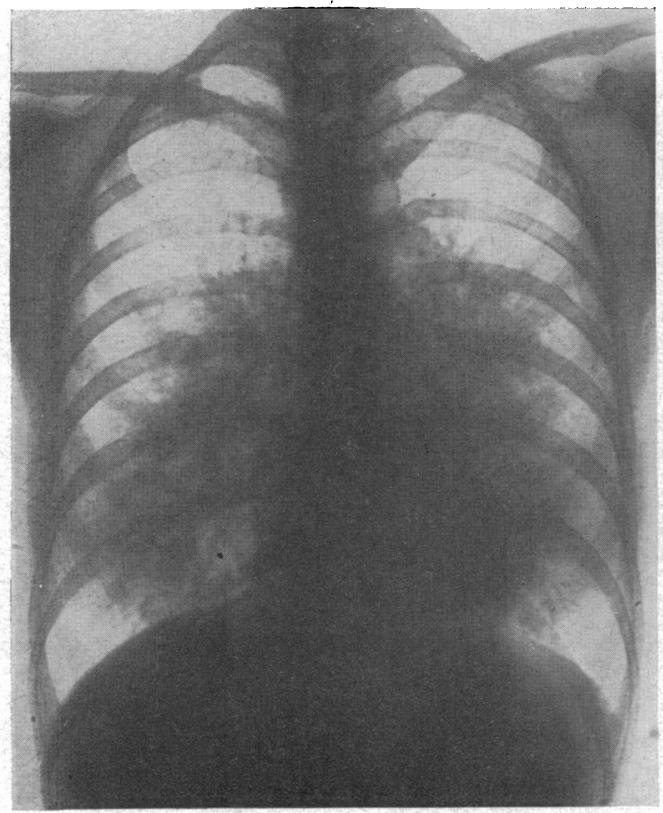

A

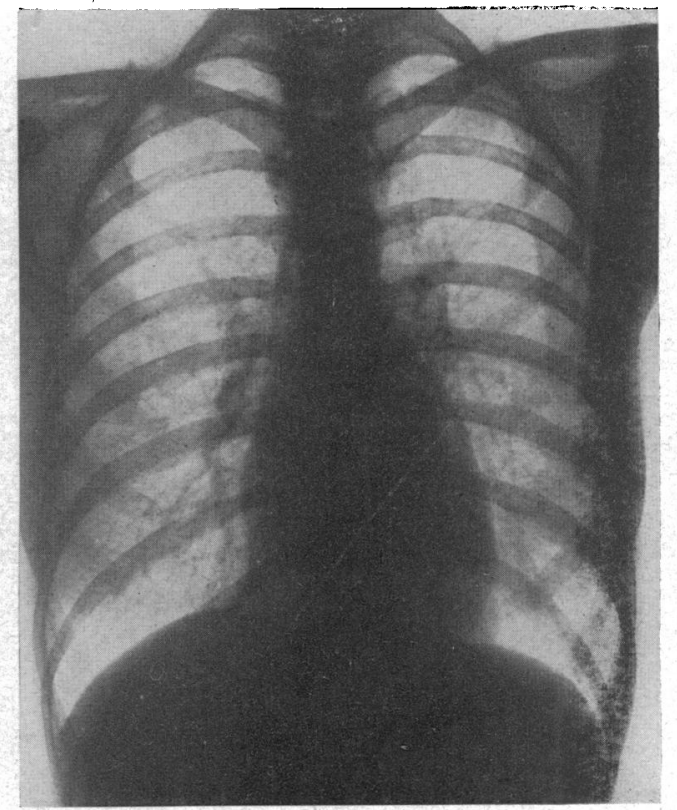

B

FIG. 17.-Mitral stenosis in normal rhythm. (A) Acute pulmonary œedema. The density is mainly perihilar. Apices and costophrenic angles clear. Diaphragm not raised. Heart hardly enlarged. (B) Two days later. CEdema gone but hilar congestion present. Heart unchanged: cardiothoracic ratio, 46 per cent.

\section{Mitral Stenosis and Acute Pulmonary Edema}

The X-ray picture of acute pulmonary œdema in mitral stenosis is not as well known as that in left ventricular failure. The attacks are often rapid in onset and of short duration. The patient frequently appears moribund, so that no X-ray is taken, yet has improved dramatically by next day and no longer shows radiological evidence of pulmonary œdema. The lung opacities do not differ from those seen with left ventricular failure, though they often vanish more rapidly. The $\mathrm{X}$-ray picture is also similar to that of paroxysmal pulmonary hæmorrhage shown by Oppenheimer and Schwartz (1933) and Schwedel (1946). Enlargement of the heart is seldom great and sometimes it is slight if not absent (Fig. 17). Hilar congestion is often severe, persisting after recovery from the attack, and the absence of much cardiac enlargement makes it more conspicuous. Acute pulmonary œdema is rare in long-standing congestive failure from mitral stenosis with gross left auricular dilatation, and I have not seen an example.

The sex incidence and the relation to the heart rhythm are of interest: 6 of my cases had mitral stenosis; all were women, and all were in normal rhythm except one, aged 69, with auricular fibrillation, in whom acute pulmonary œdema was caused by a blood transfusion (Fig. 19). In Gallavardin's (1921) series the rhythm, though not always described, was usually normal; none of Séjourne's five gravid women(1928) were stated to have an irregular pulse; and of Pezzi's four patients (1931) two were in normal rhythm and two in auricular fibrillation. When acute pulmonary œdema occurs in mitral stenosis the rhythm is usually normal (Roesler, 1943); that it also occurs with auricular fibrillation is shown by Pezzi's two cases, and by another known to me, where a man with auricular fibrillation (earlier electrocardiogram) coughed up a pint of pink frothy sputum during an attack in which he was too ill to be X-rayed; he was better the next day and a film 30 hours later showed little trace of pulmonary œdema, though there was severe pulmonary congestion from mitral stenosis. 


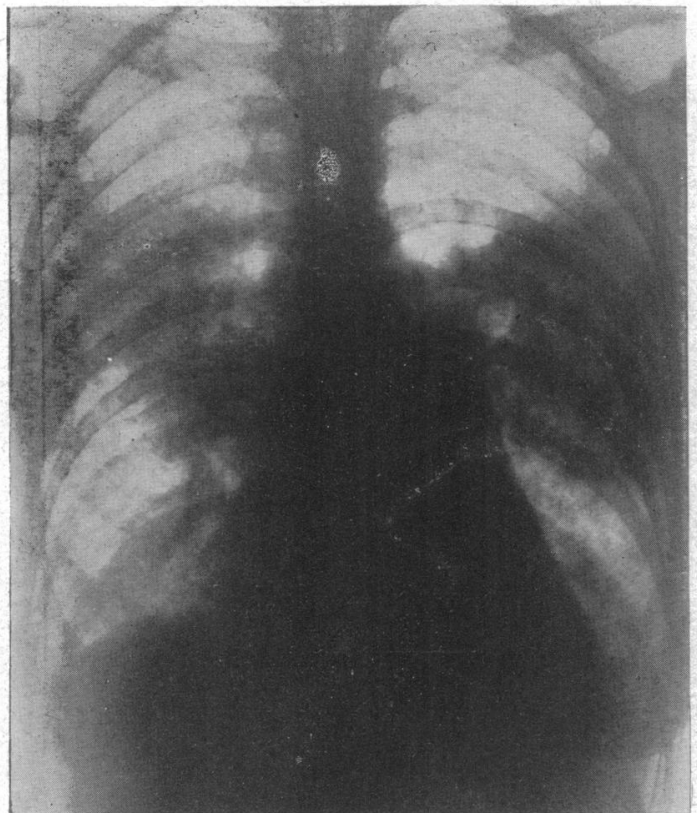

A

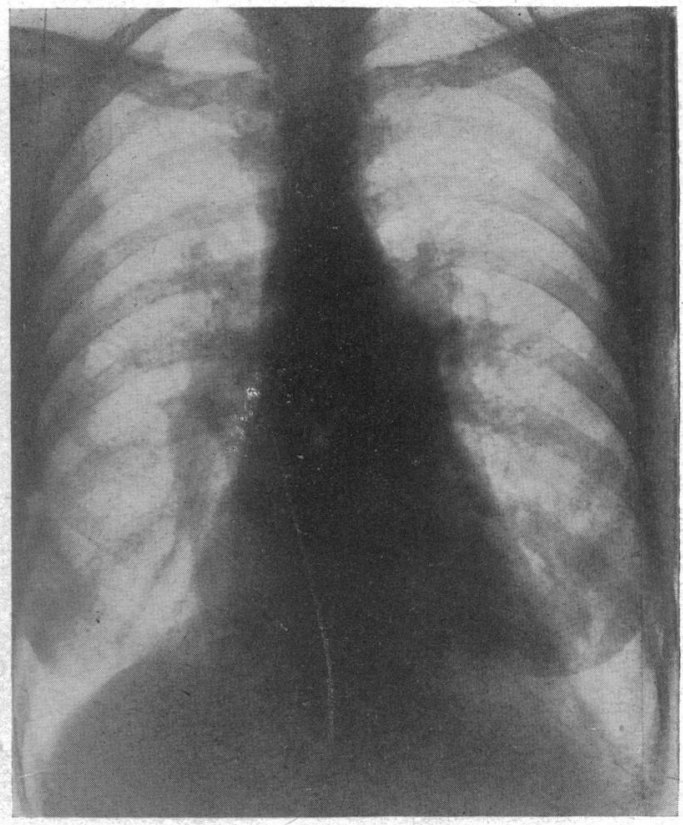

B

Fig. 18.-Mitral stenosis and normal rhythm. (A) Acute pulmonary cedema and lung infection. Extensive opacities on both sides but left more than right. Both apices clear. Diffuse cloudy shadows on the right, denser shadows on the left. Right dome of diaphragm a little raised. Pus cells in sputum. (B) Three days later after digitalis and chemotherapy, the opacities have disappeared but hilar congestion is still severe.

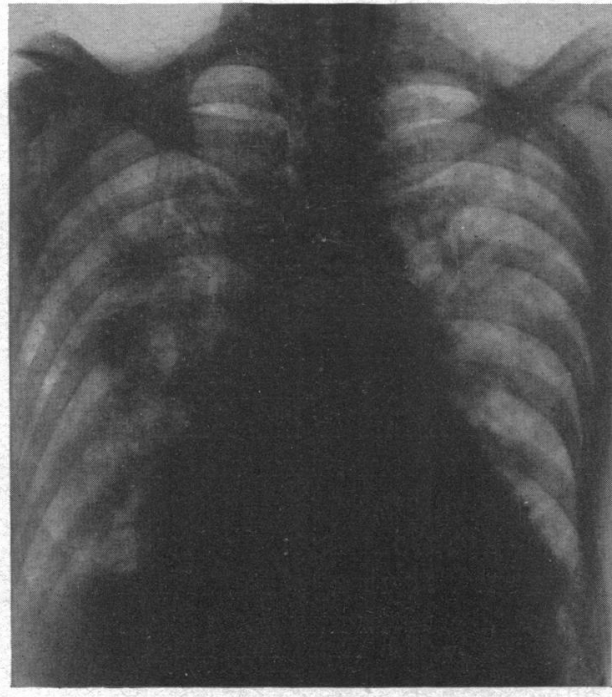

A

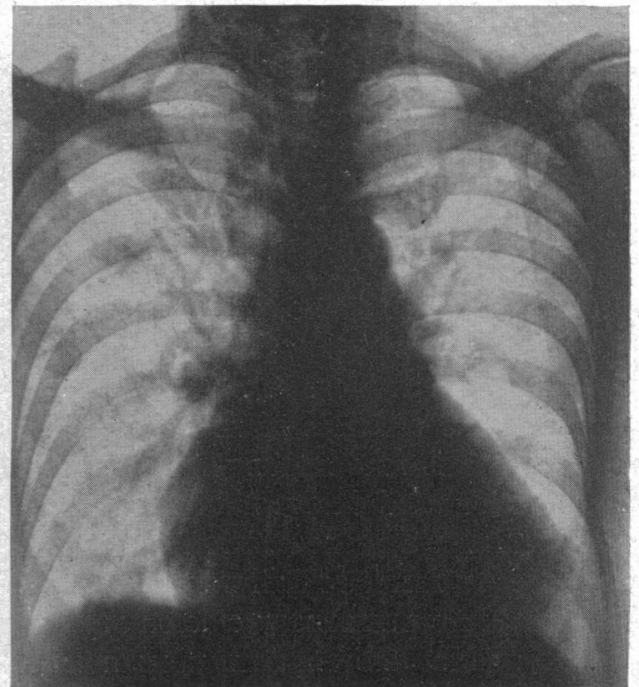

B

Fig. 19.-Mitral stenosis. Auricular fibrillation. (A) Acute pulmonary œdema, five hours after the transfusion of two pints of blood. Great loss of translucency of both lungs. Dense rounded blotchy opacities in the middle of the right lung field. Considerable cardiac enlargement. (B) Next day. Lung fields bright. Opacities gone. Right dome of the diaphragm only slightly lower. Heart unchanged in size.

In women with mitral stenosis, acute pulmonary œdema seems more liable to develop during pregnancy (Bramwell and Jones, 1944), and an attack may also be induced by the strain of labour (Séjourne, 1928; Fishberg, 1940). One of my. patients was in the sixth month of pregnancy when 
the attack developed, and in another though pregnancy was unsuspected at the time of the attack, a four-month fœtus was aborted two months later. Lenègre and Minkowski (1946) published films of a woman with mitral stenosis taken about the sixth month, during one of several attacks of acute pulmonary œdema which ceased after parturition. Doniach (1948) has shown films of a patient of Professor McMichael with mitral stenosis during an attack of acute pulmonary œdema also occurring about the sixth month of pregnancy. These patients had no toxæmia, and acute pulmonary œdema may be related to the increased rate of bloodflow in the later months of pregnancy.

\section{SUMMARY AND CONCLUSIONS}

The radiological features of acute pulmonary œdema have been studied in 20 cases, 14 due to left ventricular failure and 6 to mitral stenosis.

The X-ray film shows dense cloudy opacities spreading from the hila into the central parts of the lungs and into the lung bases, obscuring the hilar vessels and the lung markings. The apices are usually spared and the lateral costophrenic angles are often clear. The opacities are bilateral, but may be more extensive on one side, usually the right.

The shadowing often takes one of two forms, either a dense cloudy or blotchy appearance, or less commonly, a blurred speckling or branching with a generalized loss of translucency of the lung fields; pinhead stippling in the outer part of the shadowing was seen in one teleradiogram and recurred in subsequent attacks.

The changes frequently disappear quickly with treatment, once within 14 hours, but with severe left ventricular failure they are likely to persist longer.

Hilar congestion is usual and remains after the lung opacities are gone, but it, too, occasionally disappears in time. Hydrothorax is not often seen unless there is added right ventricular failure or pulmonary infarction. A little fluid, hidden in the posterior costophrenic angle, is more common, and the interlobar fissure on the right side is frequently thickened. The right dome of the diaphragm is seldom greatly raised, and the superior vena cava is not usually seen dilated.

The heart is nearly always found to be enlarged, though often less than might be expected, and it changes little in size or shape during the attack and with recovery.

The rapid disappearance of the lung opacities helps to distinguish acute pulmonary œdema from other lung disease; in this, too, it differs from the longer persisting shadow of pulmonary infarction, which is also frequently unilateral with raising of the diaphragm and a hydrothorax.

Acute pulmonary œdema in uræmic patients is the result of associated left ventricular failure and does not seem to result from uræmia without failure.

In mitral stenosis acute pulmonary œdema occurs mostly in women and nearly always with normal rhythm. The lung opacities disappear rapidly with treatment so that they are often missed. Cardiac enlargement is frequently slight but hilar congestion tends to be severe. During the later months of pregnancy there seems to be an increased predisposition towards acute pulmonary œdema in women with mitral stenosis.

I wish to thank Dr. M. H. Jupe and the staff of the Radiodiagnostic Department of the London Hospital for many excellent X-rays taken under difficult circumstances; also Professor C. Bruce Perry, Dr. F. Carlyle Hamilton and Dr. Andrew R. Riddell, both of Toronto, and Dr. K. Shirley Smith, for X-rays and clinical details of cases they have kindly permitted me to include.

I am grateful to Sir Alan Rowlands, Dr. Donald Hunter, Dr. A. E. Clark-Kennedy, Professor Clifford Wilson and Dr. Wallace Brigden, Physicians to the London Hospital, for access to cases under their care, and to Professor Dorothy Russell and Professor Wilson for the photograph of the œdematous lung.

To Dr. William Evans, Physician to the Cardiac Department, I am particularly indebted for the facilities to pursue this work and for several of the cases. Above all I thank Sir John Parkinson for his advice and encouragement at every stage, and for allowing me to use cases and material he had collected.

I am also grateful to Mr. W. D. Dicks, technician to the Cardiac Department, who took certain of the X-rays and helped with the reproductions.

$2 \mathrm{~L}$ 
Antonelli, J. (1935). Thèse de Paris.

Bedford, D. E. (1939). Lancet, 1, 1303.

Bramwell, C., and Jones, A. M. (1944). Brit. Heart J., 6, 129.

Coe, F. O., and Otell, L. S. (1932). Amer. J. Roentgenol., 27, 101.

Doniach, I. (1947). Amer. J. Roentgenol., 58, 620.

- (1949). Lancet, $2,911$.

- and McMichael, J. (1948). Personal communication.

Donzelot, E., and Heim, de Balzac R. (1947). Arch. Mal. Caur., 40, 462.

Dumas, M. A. (1941). J. Méd. Lyon, 22, 503.

Felson, H., and Heublein, G. W. (1948). Amer. J. Roentgenol., 59, 59.

Fishberg, A. M. (1940). Heart Failure. Second ed., London.

Gallavardin, L. (1921). Arch. Mal. Ceur., 14, 262.

Goodrich, W. A. (1948). Radiology, 51, 58.

Hodson, C. J. (1950). J. Fac. Radiol., 1, 176.

Lelong, M., and Bernard, J. (1937). Ann. Méd., 42, 624.

Lendrum, A. C., Scott, L. D. W., and Park, S. D. S. (1950). Quart. J. Med., 19, 249.

Lenègre, J., and Minkowski, A. (1946). Ann. Méd., 47, 253.

Nessa, C. B., and Rigler, L. G. (1941). Radiology, 37, 35.

Oppenheimer, B. S., and Schwartz, S. P. (1933). Amer. Heart J., 9, 14.

Pezzi, C. (1931). Ann. Méd., 30, 249.

Rendich, R. A., Levy, A. H., and Cove, A. M. (1941). Amer. J. Roentgenol., 46, 802.

Rennaes, S. (1948). Acta Radiol., 30, 169.

Roesler, H. (1943). Clinical Rentgenology of the Cardiovascular System. Second ed., Springfield, Ill.

Roubier, C. (1938). J. Méd. Lyon, 19, 467.

$\longrightarrow$, and Plauchu, M. (1933). Lyon Méd., 152, 137.

Schwedel, J. B. (1946). Clinical Raentgenology of the Heart. New York.

Séjourne, J. (1928). Le retrécissement mitral dans ses rapports avec l'état puerperal. Paris.

Weiss, S. (1941). Proc. New Engl. Heart Ass., 1940-41, p. 7. (1942). Bull. New York Acad. Med., 18, 93.

Werkenthin, M. (1939). Amer. J. Rantgenol., 41, 183.

White, P. D., August, S., and Michie, C. R. (1947). Amer. J. med. Sci., 214, 243.

Zdansky, E. (1933). Röntgenpraxis, 5, 248.

(1939). Röntgendiagnostik des Herzens und der grossen Gefässe. Vienna. 